\title{
SUBJECTIVITY TOWARDS EDUCATIONAL PRACTICE AND THREATS OF CONTEMPORARY TIMES: EXCEPTIONS OF REFLECTION
}

\author{
Mirosław Kowalski, Ewa Kowalska \\ University of Zielona Góra, Poland \\ E-mail: M.Kowalski@ipp.uz.zgora.pl
}

Subjectivity today is commonly referred to as a necessary condition of education. Regardless of the world-view option, of social, or religious doctrine which determines the ideological layer of the education, the problem of the subjectivity is functioning as the crucial element of the design and implementation of the educational activities. At least in individual presentations it is differently understood, nobody is already contradicting its being. With reference to the introduction - what is the subjectivity? Undoubtedly, it relates to the fundamental values of a human who is able to accept or not outside influences. Within this particular value the subjectivity is constituted (Kowalski, Falcman, 2010).

Modern ideas of education suffer from lack of the paradigmatic continuity, they commit the sin of inconsistency. Apart from the philosophical perspective of anthropology, they do not define their subjects. They constitute themselves as a methodical concept: they grow out of the technological rationality and they cross out a model of communicational rationality. The growth of educational praxeology knowledge actualises itself in isolation from the basic consideration. Inconsistency and ambiguity of ontological assumptions replaced with the indications on epistemology multiplies axiological dilemmas. Positioning itself at the edge of science - conceptions that are less sensitised to the human existential sentiment, are contained in generally accepted model - it is possible to be interpreted as an educational ideology (Kowalski, Falcman, 2012).

Is not it worth to risk the thesis, that the pupil decides first whether education is effective or not? Though it may strike with too far-reaching simplification, within certain limits (generalizations) it is acceptable. This, then, directly relates to the role of the educator. Such programmed thinking of education makes to see in an educator only the assistant that is to support the young person in his development. Supporting him - it should be added - within the limits which each pupil sets to him.

What is thus the subjectivity? In our view, it is the pillar of education, the value of harnessed to the act of its design and implementation, as well as internalized in the personality of educational entities. The quality of understanding of the designate of the concept determines a set of certain anthropological conditions, because subjectivity always refers to - in fact, determines and constitutes the extent of content, capabilities, axiological perspective to comment on- and off- world, etc. - organized in a certain way anthropologically man. Such a theoretical specification of subjectivity provides education with stability and orderliness. Does subjectivity may prevent pupil education? - certainly not, because the lack of subjectivity takes back form interactions the educational value, and the education itself, regardless of the conditions inherited within the individual pupil, is a never-ending process of proposing and encouraging, which may be the either accepted, or rejected.

We observe crisis of authority and identity. Search for substitutes compensates society no parenthetic patterns. Creating the stars of the show business as epistemic authorities in ar- 
Mirosław KOWALSKI, Ewa KOWALSKA. Subjectivity towards Educational Practice and Threats of Contemporary Times: Exceptions of Reflection

PROBLEMS

OF EDUCATION

IN THE $21^{\text {st }}$ CENTURY Volume 52, 2013

eas totally unrelated to their professional provenance and moral authorities in general, is an expression of this trend. There is no universally accepted system of values, which would allow both, to distinguish good from evil, and to clearly identify the moral tone of the phenomenon in all its, often not easy to define, nuances. The lack of uniformed axiology is certainly a factor disintegrating social structure: it influences the multiplicity (and mutual contradictory) of rules, which determine the functioning of social groups (and individuals in these groups) within the larger communities. The meanings that individuals attribute to the same fragments of reality are varied too: from extremely sceptical to even apologetic. It co-determines a variety of structural tension. On the one hand, we see the active or passive contestation of the current social order, and on the other - we see attempts that are taken, more or less successfully, to accommodate to the conditions. This is reflected in the economic stratification of society and the disproportionate dispersion (rather polarization) on the satisfaction ladder: because the major determinant of social status is the criterion of wealth. The relativism of moral norms justifies a truism of devaluing the value, but it is not known yet at which stage of the continuum of the phenomenon we are now.

An analysis of the contemporary social life allows to ascertain many interesting observations considering the balance of transformations that have taken place within it, which probably arise in the nearer or longer term, and finally - the changes that are currently in in statu nascendi. Evolution indicated here is a derivative of passing of our society into the sphere of industrial societies and of the predicted transformations into post-industrial society.

This has caused a need to redefine existing pedagogical thinking (in terms of praxeology) and allocating part of its views to the historic heritage of dubious significance for the present. The practical expression of this idea is to formulate new theoretical constructions, which are focused on particular aspects of the process of education, showing this process in a new light, often with a perspective that have not been taken into consideration yet. Moreover, very surprisingly is the fact that the spread of new theories on the basis of educational praxis is very low. This makes it impossible to assess their effectiveness, and on the other hand - it condemns practitioners for the use of ineffective methods, or eclectic improvisation: the use of methods that often have mutually exclusive basis of theoretical and ideological origins, selected on the basis of teacher intuition (Śliwerski, 2012).

\section{References}

Kowalski, M., \& Falcman, D. (2010). Świadomość aksjologiczna i podmiotowość etyczna. Analizy $i$ impresje. Kraków: Oficyna Wydawnicza „Impuls.

Kowalski, M., \& Falcman, D. (2012). Ideologie nauk społecznych - warianty interpretacyjne. Kraków: Oficyna Wydawnicza „Impuls.

Śliwerski, B. (2011). Współczesna myśl pedagogiczna. Kraków: Oficyna Wydawnicza „Impuls.

Received: March 20, 2013

Accepted: March 25, 2013

\begin{tabular}{ll} 
Mirosław Kowalski & PhD, Professor, Faculty of Education, Sociology and Health Sciences, University of \\
& Zielona Góra, Al. Wojska Polskiego 69, 65-762 Zielona Góra, Poland. \\
& E-mail: M.Kowalski@ipp.uz.zgora.pl \\
& Website: http://www.wpsnz.uz.zgora.pl/ \\
\hline \multirow{2}{*}{ Ewa Kowalska } & PhD., Faculty of Education, Sociology and Health Sciences, University of Zielona \\
& Góra, Al. Wojska Polskiego 69, 65-762 Zielona Góra, Poland. \\
& E-mail: E.Kowalska@ipp.uz.zgora.pl \\
& Website: http://www.wpsnz.uz.zgora.pl/
\end{tabular}

